\title{
Towards A Better Integration of the Sediment Biogeochemistry in the Modelling of the Coastal Systems
}

\author{
José Fortes Lopes* \\ CESAM, Departamento de Física, Universidade de Aveiro, Portugal
}

Submission: March 06, 2018; Published: May 08, 2018

Corresponding author: José Fortes Lopes, CESAM, Departamento de Física, Universidade de Aveiro, 3810-193 Aveiro, Portugal, Tel: +(351)234370821; Email: jflopes@ua.pt

\begin{abstract}
Ecological models have been signficantly improved during the last decades, leading to more realistic predictions of coastal water processes under different forcing. Even though benthic sediments play an important role in biogeochemical processes occurring in the water column, in the past, very few modelling studies have taken into account these contributions. Recent efforts are being put into the implementation of coupled models, including the biogeochemistry processes occurring at both the upper benthic layer and the water column. This step is important, as along with the river supply, benthic nutrient regeneration can contribute significantly to the phytoplankton growth and the primary production. During the validation process, due to the important number of parameters involving these models, the application of Sensitivity Analysis for selecting the most important model parameters is highly needed. The importance of these processes and tools in the ecological modelling of coastal systems is discussed in this paper.
\end{abstract}

\section{Introduction}

Very few modelling studies of coastal water systems, namely lagoon and estuarine waters, have been focused on the relationship between the biogeochemical status of the water column and the benthic sediment. In general the last one is considered as a rigid boundary, isolated from the water column and not allowed to exchange matter. Nevertheless, sediments play an important role in the biogeochemical processes occurring in the water column of coastal systems, making up, by far, the most important reservoir of nitrogen [1]. They play a key role with respect to the plankton activity: they act as regenerators of mineral nutrients for the water column, often supplying an important fraction of the nitrogen requirements by phytoplankton. During the transport and deposition, they may undergo many changes resulting from several physical, chemical and biological processes.

Diagenesis is the denomination that characterises any chemical, physical, or biological changes undergone by sediment after their initial deposition and during and after their lithification [2-5]. In general, most of the sediments biogeochemistry processes are restricted to the upper layer of the sediment column, in general, and more specifically the upper decimetres [4]. These processes can be nowadays predicted with the help of improved powerful tools, such as mathematical models, relying on both data and modern computing resources [6,7].
The assessment of the biogeochemical status of the water column, including the interplay of the sediment layer, although scientifically affordable, remains a major issue and a challenge of the modern ecological modelling of coastal water systems. There are no conceptual or technical difficulties in applying empirical parameterizations of sediment biogeochemistry models to large spatial scales, namely coastal systems. However, because these models are typically tuned to match observations at specific sites there is no guarantee they will make good predictors across larger spatial scales. Therefore, major difficulty lies in evaluating fluxes predicted by the models against observations [8-10]. Furthermore, resuspension of sediments are not, in general, taken into account while its inclusion will increase the reliability of the models to represent these environments [11].

Sediment biogeochemistry models are based on a mechanistic understanding of sediment processes, including nonlinear feedback mechanisms and temporal dependencies such as delays or storage of organic matter $[9,10,12]$. As such they are more flexible and have the potential to correctly predict system responses to changes in eutrophication status or oxygen supply, e.g., the sediment flux model applied to data from a mesocosm eutrophication experiment $[8,13]$. They are commonly based on mass conservation approaches, expressing balances between vertical transport contributions of 
selected species and biogeochemical interactions between them. In the case of most estuaries and lagoons, as they tend to be, in general, more nitrogen than phosphorus limited [14] it is very important to quantify the nitrogen cycle in the sediment.

\section{Sediment Biogeochemistry Models}

Paraska et al. [15] and Testa [9] reviewed the most popular sediment biogeochemistry models. Although the notorious advances, they found the need for a more coherent approach concerning both variables and processes, namely: aligning conceptual models of organic matter transformations with measurable parameters; gathering accurate data for model input and validation; coupling sediment models with ecological and spatially-resolved hydrodynamic models; and making the models more accessible for water quality and biogeochemistry modelling studies by developing a consistent notation through community modelling initiatives.

Recent efforts are being devoted to the implementation of a coupled ecological/sediment biogeochemistry model for a study area, the Ria de Aveiro lagoon in Portugal [16]. The eutrofication model is a standard model, representing four functional groups (phytoplankton, zooplankton, benthic vegetation and detritus). It integrates the nutrient cycling in the water column, the organic and the inorganic nutrients, the dissolved oxygen, the benthic vegetation and the primary production. The sediment model is an add-on module to the main model. Figure 1 presents the conceptual diagram of the benthic sediment biogeochemistry model and the $\mathrm{N}$ cycle in the sediments.

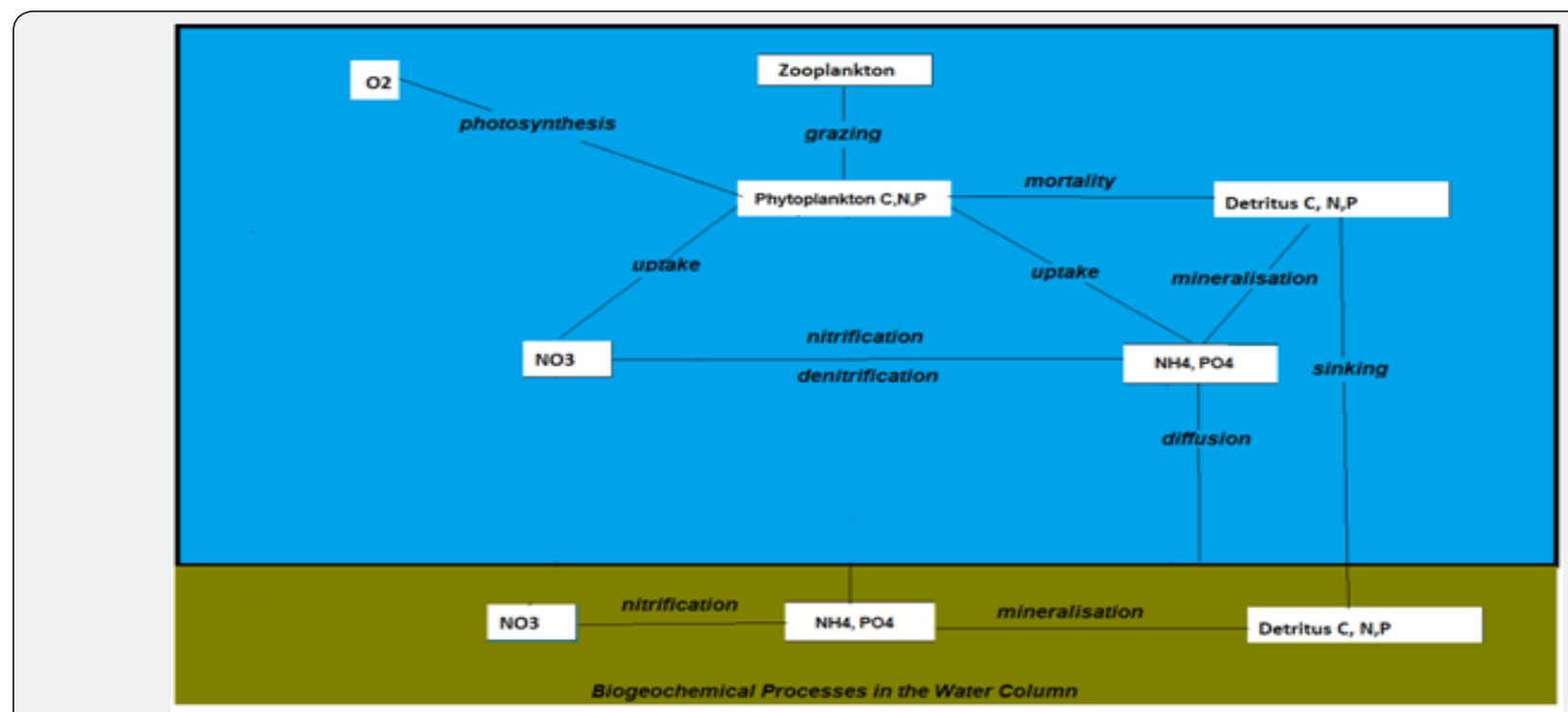

Figure 1: Conceptual diagram of the $\mathrm{N}$ cycle in the sediments (as described in Mike3, DHI, Lopes et al., 2015).
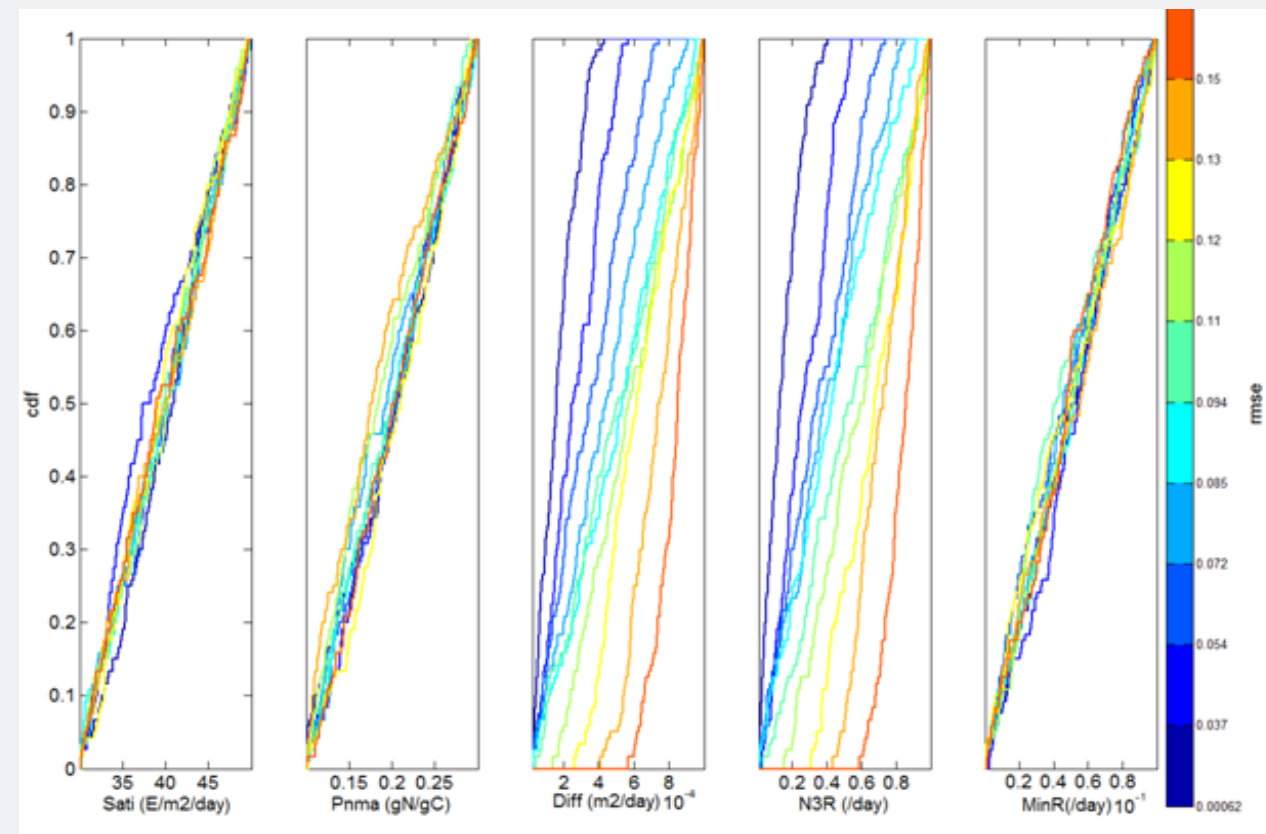

Figure 2: Example of the TN sensitivity (Distribution Functions, cdf, and rmse) to the model parameter ranges. 
The processes involving the nitrogen cycle in the sediment of Figure 2 are described in connection with the ecological/ eutrofication model state variables. The sediment biogeochemistry module consists of three state variables, the sediment organic $\mathrm{N}$ (SON), the sediment $\mathrm{NH}_{4}(\mathrm{SNH})$ and the sediment $\mathrm{NO}_{3}\left(\mathrm{SNO}_{3}\right)$. A sink of nitrogen is as well included in the model, as immobile sediment nitrogen (SNIM). The sedimentation of organic $\mathrm{N}$ or the flux of NH4 and $\mathrm{NO}_{3}$ across the sediment surface connects the state variables to the plankton $\mathrm{N}$, the detritus $\mathrm{N}$ and the inorganic IN in the water. The SON in the sediment is mineralised producing NH4, which enters the $\mathrm{SNH}$ pool. $\mathrm{NH}_{4}$ in the sediment may either be exchanged with IN in the water or nitrified into $\mathrm{NO}_{3}$ in the uppermost layer of the sediment with the help of $\mathrm{O}_{2}$. The $\mathrm{NO}_{3}$ entering the $\mathrm{SNO}_{3}$ pool may either be denitrified or exchanged with inorganic $\mathrm{N}$ in the water.

\section{Model Application: Sensitivity Analysis}

Global Sensitivity Analysis (GSA) of environmental models is an important tool aimed to characterize the impact on the model output of changes in the model input factors (e.g. parameters, initial states, input data, time/spatial resolution grid etc). For this purpose a widely-used GSA, named RSA method (Regional Sensitivity Analysis) introduced by Young et al. [17] and Spear \& Hornberger [18] is being applied to the study area in order to select the most sensitive model parameters. The method uses a Cumulative
Distribution Functions (CDFs) for each model parameter, for which the root mean squared error, RMSE, between the simulation and data for each time step along the simulation period, represents the performance metric used to synthetically measure the model accuracy. Another performance metric is the 'mvd' index based onthe Kolmogorov-Smirnov statistic, which is sensible to the 'distance' between the unconditional and conditional distributions of the performance metric [19-22].

Figures 2-4 present the first stage results of the model application, representing the sensitivity of two state variable, Total Nitrogen, TN and of the phytoplankton biomass, PC, to a wide range of five selected parameters: the diffusion coefficient of the $\mathrm{NO}_{3}$ and $\mathrm{NH}_{4}$ in the sediment (Diff) the rate of $\mathrm{NO}_{3}$ penetration into sediment (N3R), the sediment mineralisation rate (MinR) the light saturation intensity (Sati) and the phytoplankton maximum intracellular concentration (Pnma). Concerning TN the results evidence two main parameters, Dif and N3R, representing, respectively, the diffusion processes and the penetration into sediment and governing the exchanges between the sediment layer and the water column. On the other hand, it shows less sensitive to MinR, that is, to mineralisation within the sediment column. On the other hand, PC is sensitive to Sati and Pnm, which are associated to the phytoplankton growth [23].

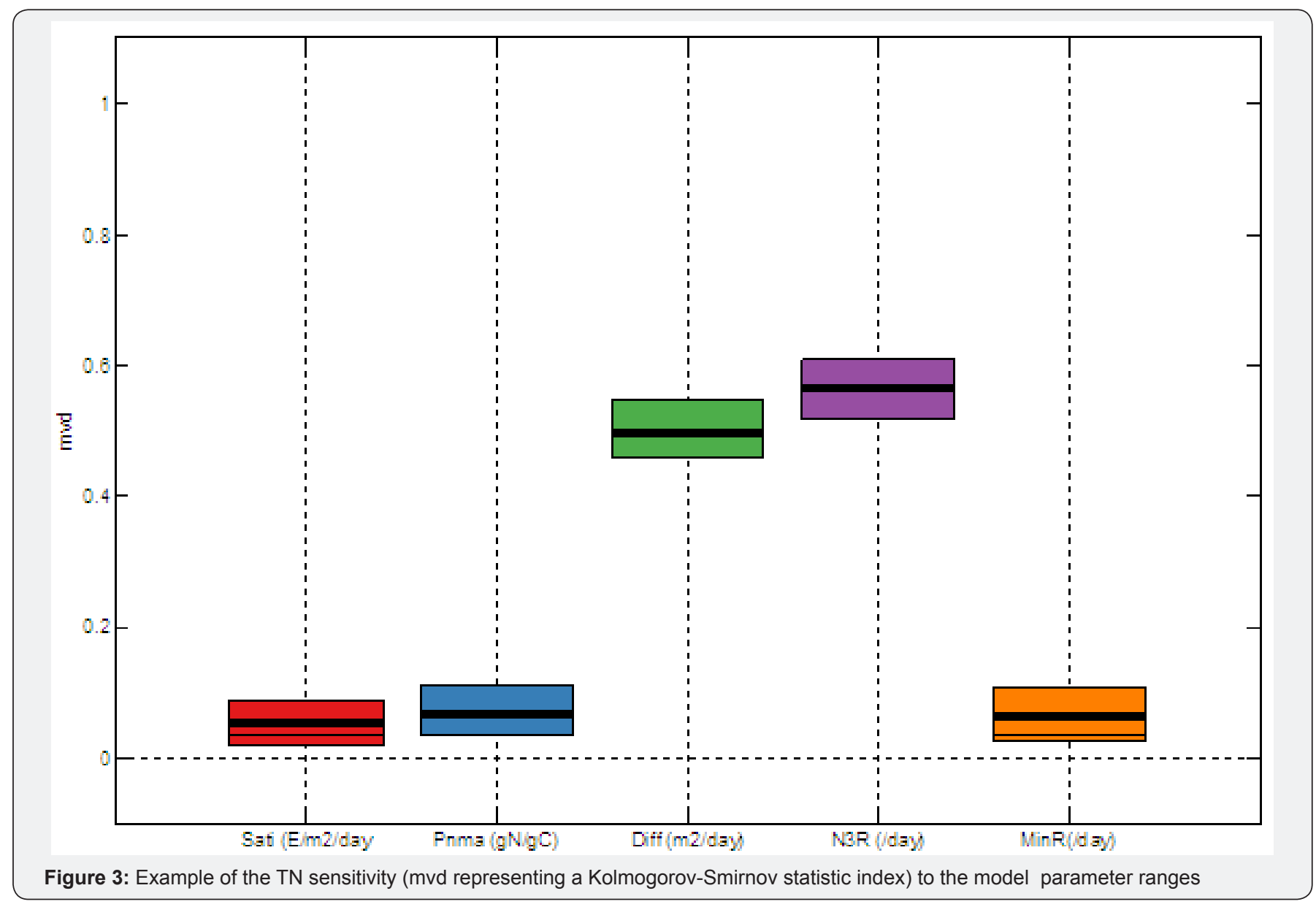




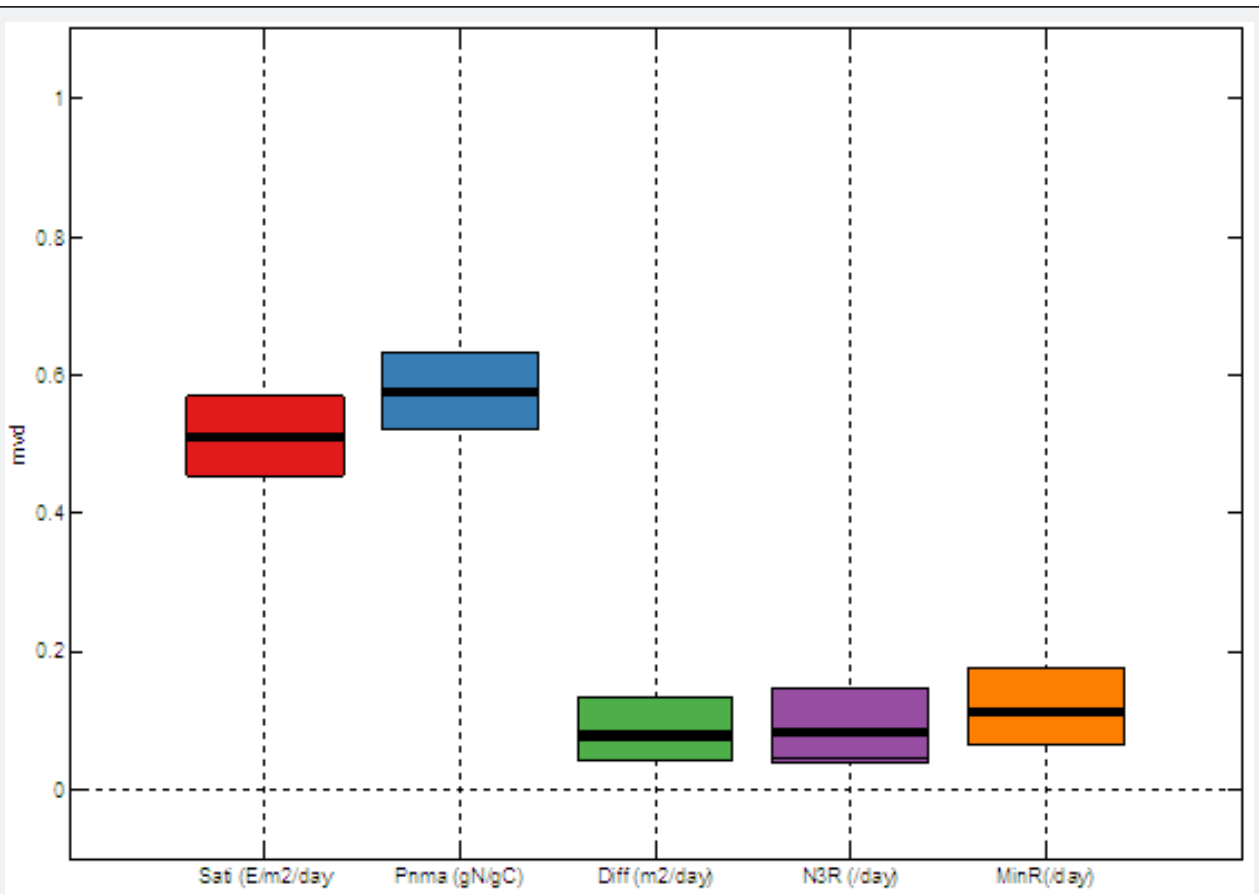

Figure 4: Example of the PC sensitivity to the model parameter ranges

\section{Conclusion}

The importance of including sediment biogeochemistry processes in the ecological modelling of coastal systems was demonstrated. These processes are responsible for regenerating nutrient, namely nitrogen, contributing to the phytoplankton growth and the primary production. On the other hand it is possible that global changes in coastal systems may affect the biogeochemistry of the water column and, therefore, of the benthic sediment. Therefore, coupled models for the water column and the benthos will be increasingly important. In order to setup such complex models very robust sensitivity method and tool will be needed.

\section{References}

1. Billen G, Lancelot C (1988) Modelling benthic nitrogen cycling in temperate coastal ecosystems. In: Blackburn TH, Sorensen (Eds,). Nitrogen Cycling in Coastal Marine Environments, Wiley and Sons, New York, USA, pp. 341-378.

2. Van Cappellen P, Wang Y (1996) Cycling of iron and manganese in surface sediments: A general theory for the coupled transport and reaction of carbon, oxygen, nitrogen, sulfur, iron, and manganese. American Journal of Science 296: 197-243.

3. Herman PMJ, Soetaert K, Middelburg JJ, Heip C, Lohse L, et al. (2001) The seafloor as the ultimate sediment trap - using sediment properties to constrain benthic-pelagic exchange processes at the Goban Spur. Deep-Sea Research II 48(14-15): 3245-3264.

4. Wijsman JWM, Herman PMJ, Middelburg JJ, Soetaert K (2002) A model for early diagenesis processes in sediments of the continental shelf of the Black Sea. Estuarine and Coast Shelf Science 54(3): 403-421.

5. Meysman FJR, Middelburg JJ, Herman PMJ, Heip CHR (2003) Reactive transport in surface sediments. II. Media: an object-oriented problemsolving environment for early diagenesis. Computers and Geosciences 29(3): 301-318.
6. Bruggemann J, Bolding K (2014) A general framework for aquatic biogeochemical models. Environ Model Softw 61: 249-265.

7. Payn RA, Helton AM, Poole GC, Izurieta C, Burgin AJ (2014) A generalized optimization model of microbially driven aquatic biogeochemistry based on thermodynamic, kinetic, and stoichiometric ecological theory. Ecol Model 294: 1-18.

8. Fennel K, Brady D, Di Toro D, Fulweiler R, Gardner W, et al. (2009) Modelling denitrification in aquatic sediments. Biogeochemistry 93(12): $159-178$.

9. Testa JM, Brady DC, Toro DMD, Boynton WR, Cornwell JC et al. (2013) Sediment flux modeling: nitrogen, phosphorus and silica cycles. Estuarine, Coastal and Shelf Science 131: 245-263.

10. Brady DC, Testa JM, DM Di Toro, Boynton WR, Kemp WM (2013) Sediment flux modeling: Calibration and application for coastal systems. Estuarine, Coastal and Shelf Science 117: 107-124.

11. Massoudieh A, Gellis A, Banks WS, Wieczorek ME (2012) Suspended sediment source apportionment in Chesapeake Bay watershed using Bayesian chemical mass balance receptor modelling. Hydrol Process 27: 3363-3374.

12. Luff R, Wallmann K, Grandel S, Schlüter M (2000) Numerical modelling of benthic processes in the deep Arabian Sea. Deep-Sea Research II 47(14): 3039-3072.

13. Di Toro DM (2001) Sediment Flux Modeling. Wiley-Interscience, New York, USA.

14. Håkanson HC, Bryhn AC, Hytteborn JK (2007) On the issue of limiting nutrient and predictions of cyanobacteria in aquatic systems. Sci Tot Environ 379(1): 89-108.

15. Paraska DW, Hipsey MR, Salmon SU (2015) Sediment diagenesis models: Review of approaches, challenges and 25 opportunities. Environ Modell Softw 61(C): 297-325.

16. Lopes JF, Vaz N, Ferreira JA, Dias JM (2015) Assessing the state of the lower level of the trophic web of a temperate lagoon, in situations of light or nutrient stress: a modelling study. Ecol Model 313: 59-76. 
17. Young PC, Spear RC, Hornberger GM (1978) Modelling badly defined systems: some further thoughts. In: Proceedings SIMSIG Conference. Canberra, Australia, pp. 24-32.

18. Spear RC, Hornberger GM (1980) Eutrophication in peel inlet e II Identification of critical uncertainties via generalized sensitivity analysis. Water Res 14(1): 43-49.

19. Pianosi F, Beven K, Freer JE, Hall JW, Rougier J, et al. (2016) Sensitivity analysis of environmental models: A systematic review with practical workflow. Environmental Modelling and Software 79: 214-232.

20. Pianosi F, Wagener T (2015a) A simple and efficient method for global sensitivity analysis based on cumulative distribution functions. Environmental Modelling \& Software 67: 1-11.
21. Pianosi F, Sarrazin F, Wagener T (2015b) A Matlab toolbox for Global Sensitivity Analysis. Environmental Modelling \& Software 70: 80-85.

22. Sarrazin F, Pianosi F, Wagener T (2016) Global Sensitivity Analysis of environmental models: Convergence and validation. Environmental Modelling Software 79: 135-152.

23. Droop MR (1973) Some thoughts on nutrient limitation in algae. Journal of Phycology 9(3): 264-272.

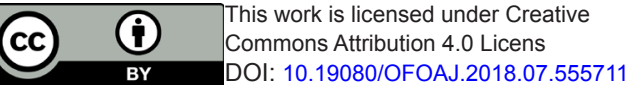

Your next submission with Juniper Publishers will reach you the below assets

- Quality Editorial service

- Swift Peer Review

- Reprints availability

- E-prints Service

- Manuscript Podcast for convenient understanding

- Global attainment for your research

- Manuscript accessibility in different formats ( Pdf, E-pub, Full Text, Audio)

- Unceasing customer service

Track the below URL for one-step submission https://juniperpublishers.com/online-submission.php 